\title{
Extractability and availability index of sulphur in selected soils of Odisha
}

\author{
Dhaneshwar Padhan $^{1 *}$, Arup Sen ${ }^{1}$ and Pragyan Paramita Rout ${ }^{2}$ \\ ${ }^{1}$ Department of Agricultural Chemistry and Soil Science, Bidhan Chandra Krishi Viswavidyalaya, Mohanpur- \\ 741235 (West Bengal), INDIA \\ ${ }^{2}$ Department of Soil Science and Agricultural Chemistry, Tamil Nadu Agricultural University, Coimbatore-641003 \\ (T.N), INDIA \\ "Corresponding author. E-mail: dhaneshwar.padhan@rediffmail.com
}

Received: January 22, 2016; Revised received: July 20, 2016; Accepted: November 2, 2016

\begin{abstract}
We aimed to evaluate the extractability of two reagents viz.0.15\% $\mathrm{CaCl}_{2} \& 0.01 \mathrm{M} \mathrm{Ca}\left(\mathrm{H}_{2} \mathrm{PO}_{4}\right)$ for sulphur along with the sulphur availability index of mixed red and black soils. For this 86 soil samples were collected from mixed red and black soil regions and extracted with these solutions. Results showed that both these solutions extracted nearly similar amount of sulphur in black soils while the Ca phosphate solution extracted higher amount $\left(13.9 \mathrm{mgkg}^{-1}\right)$ compared to Ca chloride solution $\left(11.5 \mathrm{mgkg}^{-1}\right)$ in red soil regions. Considering all the 86 soil samples tested, there was an excellent correlation between the extractable sulphur, the highest correlation being reported from black soils $\left(R^{2}=0.97\right)$. Sulphur availability index was found to be higher in black soils (mean 6.6) compared to red soils (mean 5.1). Also the content of adsorbed sulphur was found to be high in red soils $\left(2.4 \mathrm{mgkg}^{-1}\right) \mathrm{compared} \mathrm{to}^{-1}$ black soils $\left(1.5 \mathrm{mgkg}^{-1}\right)$. Correlation matrix and regression equations (Ca phosphate $\mathrm{S}=5.00+0.77 \mathrm{Ca}$ chloride $\mathrm{S}$ ) were worked out between the extractable sulphur and soil properties to justify the results.
\end{abstract}

Keywords: Adsorbed sulphur, Ca chloride, Ca phosphate, Extractable sulphur, Regression equation, Sulphur Availability index

\section{INTRODUCTION}

Sulphur $(\mathrm{S})$ is one of the essential secondary macronutrient elements required for optimum growth, metabolism and development of all plants and is rightly called as the fourth major plant nutrient (Rathore et al., 2015). It plays vital role in different physiological and biochemical functions in plants. However, the nonavailability of $\mathrm{S}$ in adequate amount in soils leads to reduction in crop yields. Sulphur deficiency in crops has become increasingly widespread all over the world soils (Zhao et al., 2002; Scherer, 2009), the reason being the nutrient management strategies mainly depended on application of NPK fertilizers, ignoring the replenishment of other nutrients through fertilizers or organic sources (Sahrawat et al., 2009) . Apart from that, progressively higher removal of sulphur owing to high production level led to appearance of sulphur deficiency (Tandon, 2011). Such soil S deficiency necessitates the application of S-fertilizer based on soil test values in order to harvest a good crop yields (Pareek, 2007) as supply of S through the application of manure is generally meagre because these resources are sparingly used and in small quantities (Rego et al., 2003). In soils, S mostly remains in organic combination, constituting more than 95\% (Wang et al., 2006) of total sulphur. Sulphate-S is the form plants prefer to uptake, which availability depends upon the mineralization of organic $\mathrm{S}$ in soils. Although, mineralization of organic $\mathrm{S}$ is solely a microbes mediated process, the availability of sulphate is controlled by $\mathrm{pH}$, organic carbon and clay content of soils through some adsorp- tion-desorption mechanism. Soils low in $\mathrm{pH}$ and high clay content bind the sulphate-S on the edge of colloidal matrix and plants find it difficult to uptake the same from the exchange sites. The adsorption of sulphate on clay matrix varies with the soil types. Red soils adsorb more sulphate-S than black soils possibly because of lower $\mathrm{pH}$ and high content of oxides of iron and aluminium (Ghosh and Dash, 2012). High organic carbon content of black soils supply adequate amount of $\mathrm{S}$ in soils though available $\mathrm{S}$ content of black soils of Indore were found to be below the critical limit (Padhan, 2014). Sulphur uptake and assimilation varies with crop species, the higher amount required by oilseeds while cereals have least requirement. However, the rate of uptake depends upon the availability of $S$ in the plant root zone during the active growing stage of crops as its availability in soils for plant uptake is mostly influenced by various soil properties (Haneklaus et al., 2002; Biswas et al., 2003).

Various methods have been proposed to evaluate the amounts of soil S available for plant uptake (Mc Grath \& Zhao, 1994). Most of the methods for soil S testing involve extraction of soil with a weak salt solution viz. $0.15 \% \mathrm{CaCl}_{2}$ (Williams and Steinbergs, 1959) and $0.01 \mathrm{M} \mathrm{Ca}\left(\mathrm{H}_{2} \mathrm{PO}_{4}\right)$ solution (Fox et al., 1964). Phosphate containing solution performs better in soils where adsorption of sulphate-S is predominant (viz. soils high in oxides of $\mathrm{Fe} \& \mathrm{Al}$ having acidic soil $\mathrm{pH}$ ) as phosphate displaces the sulphate ion from exchange complex in to solution and calcium ion flocculates the soil colloids (Fox et al., 1964). It is therefore important 
that the factor controlling the extractability of different reagents for $\mathrm{S}$ in soils are well understood in order to predict the availability of $\mathrm{S}$. Though, $\mathrm{S}$ availability in soil is regulated by various soil properties, several $S$ availability indices have been used as an indicator of plant available S. Sulphur Availability Index (SAI) proposed by Donahue et al. (1977) is one such index. According to this concept, if a soil contains sulphate-S just above the critical limit with low organic matter content, then it will not be enough to consider the soil sufficient in available sulphur, since low organic matter content can't support the inorganic $\mathrm{S}$ fraction in case of any depletion.

Knowledge regarding the sulphur supplying capacity and the influence of soil properties on its availability in mixed red and black soils of Bargarh district of Odisha is meagre (Padhan, 2014; Padhan et al., 2016). Therefore, the objective of the study were to determine the $S$ supplying capacity of mixed red and black soils and also their Sulphur Availability Index (SAI) in the study areas.

\section{MATERIALS AND METHODS}

Eighty six (86) surface soil $(0-20 \mathrm{~cm})$ samples were collected from mixed red and black soil region of Bargarh district of Odisha where the red soils occupied slightly higher elevation compared to black soils. The study area (fig.1) is having an elevation of $189.3 \mathrm{~m}$ above the msl. The soils were slightly coarser in texture with moderate clay content. The samples were air dried, ground to pass through $2 \mathrm{~mm}$ sieve and stored in polythene bags in a dry place. Soil $\mathrm{pH}$ was estimated in soil: $0.01 \mathrm{M} \mathrm{CaCl}{ }_{2}$ solution as described by Jackson (1973). Soil organic carbon content was determined by Walkley and Black method (1934). Extractable sulphur was determined by extracting soils with $0.15 \% \mathrm{CaCl}_{2}$ solution (Williams and Steinbergs, 1959) and 0.01M $\mathrm{Ca}\left(\mathrm{H}_{2} \mathrm{PO}_{4}\right)$ solution (Fox et al., 1964). Phosphate containing extractant was used to extract both water soluble and adsorbed sulphate while the $\mathrm{Cl}^{-}$based extractant was used to extract mainly water soluble sulphate. Sulphur in the extract was determined turbidimetrically (Chesnin and Yien, 1950). Sulphur Availability Index (SAI) was calculated by the formula proposed by Do-

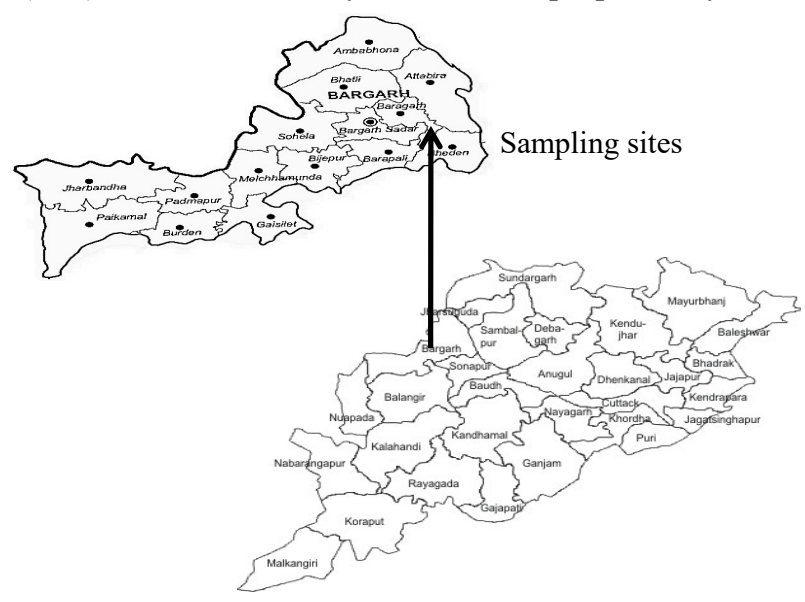

Fig. 1. Map showing location of sampling sites. nahue et al. (1977) as outlined by Basumatary and Das (2012).

$\mathrm{SAI}=\left(0.4 \times \mathrm{CaCl}_{2}\right.$ extractable $\mathrm{SO}_{4}{ }^{=}$in $\mathrm{mg} \mathrm{kg}^{-1}$ soil $)+$ $\%$ organic matter

Simple correlation was worked out relating extractable $\mathrm{S}$ with SAI and soil properties by standard statistical methods.

\section{RESULTS AND DISCUSSION}

Soil properties: The prominent soils of the district are mixed red and black type with the former occupying the upper topographic position while the later occurs in lower topographic regions. The results on some of the soil properties revealed that the soil $\mathrm{pH}$ ranged from 4.91 to 6.47 with average of 5.86 in red soil regions indicating that the soils were moderately acidic to slightly acidic while the soils of black soil region indicated that the soils were slightly acidic to neutral in reaction which ranged from 6.52 to 7.59 with mean 7.03 (Table $1 \& 2$ ). Occurrence of such low $\mathrm{pH}$ values in the red soil regions could be due to the leaching of bases from the upper topographic position leaving behind the oxides of iron and aluminium which gives lower $\mathrm{pH}$ values to the soils (Sehgal, 2012). Black soils have high $\mathrm{pH}$ which may be due to presence of high exchangeable cations on the exchange complex and may be due to calcareousness (Kaushal et al., 1986) which in turn is controlled by topography and physiographic position. Accumulations of basic cations especially $\mathrm{Ca}$ and $\mathrm{Mg}$ in the low lying regions and their subsequent concentration leads to high $\mathrm{pH}$ values of the black soils. Similar reports were also observed in the low land soils of some villages of Nimapara block under the coastal plain agro-climatic zone of Odisha (Satpathy et al., 2015). Padhan et al. (2015) found that the rice soils of the study regions were acidic to neutral in reaction. The soil organic carbon (SOC) content of red soils were found be low with average of $2.8 \mathrm{~g} \mathrm{~kg}^{-1}$ while that of black soil regions were found to be well above the low status of SOC content (mean $4.6 \mathrm{~g} \mathrm{~kg}^{-1}$ ). The magnitude of SOC content in black soils of Bargarh agreed with the findings of Padhan et al. (2015). Black soils contain high organic carbon as compared to red soil (Thakrey et al., 2012). High SOC content in black soils compared to red soils could be due to higher rate of oxidation of organic matter in the later owing to its occurrence in the upper topographic position while the high clay content of former possibly make some clay-organic complex and lowering its rapid decomposition.

Extractable sulphur content in soils: Amount of sulphur extracted by several extractants varies with the soil properties. The results of extractable $\mathrm{S}$ in soil samples extracted by $\mathrm{Ca}$ chloride $\left(0.15 \% \mathrm{CaCl}_{2}\right.$ solution) and $\mathrm{Ca}$ phosphate $\left(0.01 \mathrm{M} \mathrm{Ca} \mathrm{H}_{2} \mathrm{PO}_{4}\right)$ reagents were presented in table $3 \& 4$. Results showed that high amount of Ca phosphate extractable S compared to Ca chloride was found in both the red and black soils. However, the amount of $\mathrm{S}$ extracted by both these extractants in black soils was not much differing compared to red soils. It is expected that phosphate containing solution extract $\mathrm{S}$ from both the adsorbed and readily available pool while $\mathrm{Ca}$ chloride 
Table 1. Soil organic carbon (SOC) content and $\mathrm{pH}$ of red soils (Mean values of three replications).

\begin{tabular}{|c|c|c|}
\hline Sample No. & pH & $\begin{array}{l}\text { Soil organic car- } \\
\text { bon }\left(\mathrm{gkg}^{-1}\right)\end{array}$ \\
\hline 1 & $4.93 \pm 0.05$ & $1.4 \pm 0.21$ \\
\hline 2 & $5.10 \pm 0.02$ & $2.1 \pm 0.10$ \\
\hline 3 & $5.06 \pm 0.05$ & $2.3 \pm 0.20$ \\
\hline 4 & $5.28 \pm 0.06$ & $2.2 \pm 0.10$ \\
\hline 5 & $5.61 \pm 0.04$ & $3.1 \pm 0.06$ \\
\hline 6 & $5.04 \pm 0.06$ & $2.6 \pm 0.15$ \\
\hline 7 & $4.91 \pm 0.03$ & $2.5 \pm 0.12$ \\
\hline 8 & $6.27 \pm 0.04$ & $1.4 \pm 0.12$ \\
\hline 9 & $6.34 \pm 0.06$ & $1.7 \pm 0.25$ \\
\hline 10 & $5.86 \pm 0.07$ & $2.6 \pm 0.15$ \\
\hline 11 & $6.31 \pm 0.04$ & $3.3 \pm 0.21$ \\
\hline 12 & $5.82 \pm 0.06$ & $3.4 \pm 0.26$ \\
\hline 13 & $5.67 \pm 0.05$ & $2.7 \pm 0.26$ \\
\hline 14 & $5.82 \pm 0.05$ & $2.5 \pm 0.36$ \\
\hline 15 & $5.90 \pm 0.02$ & $2.7 \pm 0.20$ \\
\hline 16 & $5.29 \pm 0.05$ & $2.3 \pm 0.10$ \\
\hline 17 & $6.27 \pm 0.05$ & $3.1 \pm 0.25$ \\
\hline 18 & $6.47 \pm 0.09$ & $3.2 \pm 0.20$ \\
\hline 19 & $6.14 \pm 0.03$ & $3.5 \pm 0.30$ \\
\hline 20 & $6.19 \pm 0.03$ & $3.6 \pm 0.20$ \\
\hline 21 & $6.22 \pm 0.02$ & $3.5 \pm 0.20$ \\
\hline 22 & $6.22 \pm 0.03$ & $3.4 \pm 0.31$ \\
\hline 23 & $6.03 \pm 0.04$ & $3.1 \pm 0.15$ \\
\hline 24 & $6.09 \pm 0.04$ & $3.3 \pm 0.15$ \\
\hline 25 & $5.34 \pm 0.10$ & $3.5 \pm 0.30$ \\
\hline 26 & $5.46 \pm 0.05$ & $3.2 \pm 0.25$ \\
\hline 27 & $5.53 \pm 0.04$ & $3.6 \pm 0.15$ \\
\hline 28 & $5.84 \pm 0.06$ & $2.8 \pm 0.25$ \\
\hline 29 & $5.86 \pm 0.04$ & $3.1 \pm 0.25$ \\
\hline 30 & $6.16 \pm 0.03$ & $2.9 \pm 0.15$ \\
\hline 31 & $6.16 \pm 0.06$ & $2.5 \pm 0.35$ \\
\hline 32 & $6.27 \pm 0.05$ & $2.5 \pm 0.12$ \\
\hline 33 & $6.42 \pm 0.05$ & $2.6 \pm 0.42$ \\
\hline 34 & $6.21 \pm 0.05$ & $3.1 \pm 0.26$ \\
\hline 35 & $6.05 \pm 0.07$ & $2.8 \pm 0.10$ \\
\hline 36 & $6.30 \pm 0.05$ & $2.7 \pm 0.17$ \\
\hline 37 & $6.08 \pm 0.04$ & $2.6 \pm 0.20$ \\
\hline 38 & $6.25 \pm 0.04$ & $3.0 \pm 0.20$ \\
\hline 39 & $6.39 \pm 0.03$ & $2.7 \pm 0.21$ \\
\hline 40 & $5.66 \pm 0.04$ & $2.4 \pm 0.26$ \\
\hline 41 & $5.91 \pm 0.06$ & $2.7 \pm 0.20$ \\
\hline 42 & $5.42 \pm 0.04$ & $2.4 \pm 0.26$ \\
\hline Range & $4.91-6.47$ & 1.4- 3.6 \\
\hline Mean & 5.86 & 2.8 \\
\hline $\mathrm{SD}$ & 0.45 & 0.53 \\
\hline
\end{tabular}

extract only the readily available pool of $\mathrm{S}$ in soils. This happens to be due the greater anion replacing capacity of phosphate ion compared to chloride ion. High content of oxides of Fe and Al in red soils (Ghosh and Dash, 2012) and low $\mathrm{pH}$ values exhibit positive charge on edge and surface of soil colloids which suppose to bind the sulphate ion rendering its availability for plant uptake. Soil $\mathrm{pH}$ greatly affects the extraction of $\mathrm{S}$ from soil by $\mathrm{Ca}$ chloride and $\mathrm{Ca}$ phosphate. When soil $\mathrm{pH}$ is in the neutral
Table 2. Soil organic carbon (SOC) content and $\mathrm{pH}$ of black soils (Mean values of three replications).

\begin{tabular}{|c|c|c|}
\hline Serial No. & pH & $\begin{array}{c}\text { Soil organic carbon } \\
\left(\mathrm{gkg}^{-1}\right)\end{array}$ \\
\hline 1 & $6.58 \pm 0.09$ & $2.7 \pm 0.21$ \\
\hline 2 & $7.10 \pm 0.07$ & $2.3 \pm 0.20$ \\
\hline 3 & $7.49 \pm 0.04$ & $2.6 \pm 0.25$ \\
\hline 4 & $6.96 \pm 0.06$ & $3.3 \pm 0.20$ \\
\hline 5 & $6.58 \pm 0.06$ & $5.2 \pm 0.35$ \\
\hline 6 & $6.57 \pm 0.06$ & $5.7 \pm 0.50$ \\
\hline 7 & $6.83 \pm 0.05$ & $2.5 \pm 0.31$ \\
\hline 8 & $6.61 \pm 0.04$ & $5.5 \pm 0.23$ \\
\hline 9 & $6.79 \pm 0.04$ & $3.5 \pm 0.36$ \\
\hline 10 & $6.62 \pm 0.06$ & $3.5 \pm 0.35$ \\
\hline 11 & $7.16 \pm 0.05$ & $4.2 \pm 0.30$ \\
\hline 12 & $7.16 \pm 0.06$ & $4.5 \pm 0.35$ \\
\hline 13 & $7.31 \pm 0.05$ & $4.9 \pm 0.20$ \\
\hline 14 & $7.40 \pm 0.05$ & $4.7 \pm 0.45$ \\
\hline 15 & $7.54 \pm 0.09$ & $5.5 \pm 0.40$ \\
\hline 16 & $7.24 \pm 0.05$ & $4.4 \pm 0.20$ \\
\hline 17 & $7.29 \pm 0.06$ & $3.5 \pm 0.30$ \\
\hline 18 & $7.17 \pm 0.05$ & $3.5 \pm 0.21$ \\
\hline 19 & $7.39 \pm 0.04$ & $3.6 \pm 0.30$ \\
\hline 20 & $6.88 \pm 0.04$ & $5.4 \pm 0.20$ \\
\hline 21 & $6.86 \pm 0.08$ & $6.2 \pm 0.30$ \\
\hline 22 & $6.85 \pm 0.07$ & $3.5 \pm 0.20$ \\
\hline 23 & $6.52 \pm 0.07$ & $5.3 \pm 0.17$ \\
\hline 24 & $6.60 \pm 0.04$ & $5.2 \pm 0.17$ \\
\hline 25 & $6.67 \pm 0.07$ & $6.4 \pm 0.15$ \\
\hline 26 & $6.84 \pm 0.06$ & $5.5 \pm 0.40$ \\
\hline 27 & $6.89 \pm 0.03$ & $5.5 \pm 0.31$ \\
\hline 28 & $6.96 \pm 0.07$ & $4.3 \pm 0.26$ \\
\hline 29 & $6.84 \pm 0.07$ & $4.6 \pm 0.26$ \\
\hline 30 & $7.37 \pm 0.05$ & $4.6 \pm 0.35$ \\
\hline 31 & $7.59 \pm 0.05$ & $5.5 \pm 0.35$ \\
\hline 32 & $7.34 \pm 0.12$ & $4.9 \pm 0.35$ \\
\hline 33 & $7.19 \pm 0.06$ & $5.1 \pm 0.25$ \\
\hline 34 & $7.38 \pm 0.04$ & $6.1 \pm 0.25$ \\
\hline 35 & $7.59 \pm 0.03$ & $5.4 \pm 0.25$ \\
\hline 36 & $7.21 \pm 0.03$ & $4.8 \pm 0.31$ \\
\hline 37 & $7.52 \pm 0.04$ & $4.5 \pm 0.40$ \\
\hline 38 & $6.90 \pm 0.02$ & $4.4 \pm 0.15$ \\
\hline 39 & $6.79 \pm 0.07$ & $4.2 \pm 0.23$ \\
\hline 40 & $6.64 \pm 0.06$ & $4.1 \pm 0.25$ \\
\hline 41 & $6.65 \pm 0.10$ & $3.6 \pm 0.35$ \\
\hline 42 & $6.82 \pm 0.06$ & $5.5 \pm 0.31$ \\
\hline 43 & $7.19 \pm 0.07$ & $5.2 \pm 0.25$ \\
\hline 44 & $7.20 \pm 0.06$ & $4.8 \pm 0.30$ \\
\hline Range & $6.52-7.59$ & $2.3-6.4$ \\
\hline Mean & 7.03 & 4.60 \\
\hline $\mathrm{SD}$ & 0.32 & 1.01 \\
\hline
\end{tabular}

and alkaline range, soil particles predominantly carry negative charges and sulphate ions are present in soil solution, leading to extraction of similar amounts of $\mathrm{S}$ by both $\mathrm{Ca}$ chloride and $\mathrm{Ca}$ phosphate (Sahrawat et al., 2009).The high extractable sulphur content in black soils could be due to the high organic carbon content of such soils. Contrary to that despite of having high content of clay in black soils there was no significant adsorption of sulphate compared to red soils because $\mathrm{pH}$ of soils played the dominant role in controlling the adsorption-desorption of sulphate ion in soils. Adsorbed S usually found in soils 
Table 3. Extractable $\mathrm{S}\left(\mathrm{mg} \mathrm{kg}^{-1}\right)$ extracted with $0.15 \%$ $\mathrm{CaCl}_{2}(\mathrm{Ca}$ chloride $\mathrm{S})$ and $0.01 \mathrm{M} \mathrm{Ca}\left(\mathrm{H}_{2} \mathrm{PO}_{4}\right)(\mathrm{Ca}$ phosphate $\mathrm{S})$ solutions in 42 soil samples of red soil regions.

\begin{tabular}{|c|c|c|}
\hline Sample No. & $\begin{array}{c}0.15 \% \mathrm{CaCl}_{2} \mathrm{ex}- \\
\text { tractable } \mathrm{S}\end{array}$ & $\begin{array}{c}0.01 \mathrm{M} \mathrm{Ca}\left(\mathrm{H}_{2} \mathrm{PO}_{4}\right) \\
\text { extractable } \mathrm{S}\end{array}$ \\
\hline 1 & $9.3 \pm 0.15$ & $14.9 \pm 0.31$ \\
\hline 2 & $10.3 \pm 0.17$ & $14.6 \pm 0.25$ \\
\hline 3 & $10.6 \pm 0.15$ & $14.4 \pm 0.30$ \\
\hline 4 & $11.4 \pm 0.15$ & $13.6 \pm 0.26$ \\
\hline 5 & $11.6 \pm 0.36$ & $13.5 \pm 0.30$ \\
\hline 6 & $10.4 \pm 0.25$ & $14.5 \pm 0.26$ \\
\hline 7 & $9.6 \pm 0.47$ & $15.5 \pm 0.36$ \\
\hline 8 & $11.5 \pm 0.30$ & $13.1 \pm 0.15$ \\
\hline 9 & $11.5 \pm 0.30$ & $12.4 \pm 0.25$ \\
\hline 10 & $12.5 \pm 0.40$ & $13.3 \pm 0.21$ \\
\hline 11 & $12.5 \pm 0.26$ & $13.5 \pm 0.31$ \\
\hline 12 & $11.9 \pm 0.35$ & $13.3 \pm 0.26$ \\
\hline 13 & $12.4 \pm 0.45$ & $14.4 \pm 0.25$ \\
\hline 14 & $14.0 \pm 0.21$ & $15.6 \pm 0.21$ \\
\hline 15 & $11.7 \pm 0.40$ & $14.6 \pm 0.35$ \\
\hline 16 & $11.2 \pm 0.25$ & $14.5 \pm 0.31$ \\
\hline 17 & $11.0 \pm 0.31$ & $12.5 \pm 0.36$ \\
\hline 18 & $11.5 \pm 0.32$ & $13.2 \pm 0.30$ \\
\hline 19 & $12.5 \pm 0.25$ & $13.5 \pm 0.31$ \\
\hline 20 & $12.4 \pm 0.31$ & $13.7 \pm 0.26$ \\
\hline 21 & $12.2 \pm 0.36$ & $14.5 \pm 0.31$ \\
\hline 22 & $11.6 \pm 0.20$ & $14.2 \pm 0.36$ \\
\hline 23 & $11.6 \pm 0.32$ & $13.5 \pm 0.30$ \\
\hline 24 & $12.9 \pm 0.35$ & $15.5 \pm 0.23$ \\
\hline 25 & $12.5 \pm 0.40$ & $13.5 \pm 0.31$ \\
\hline 26 & $11.6 \pm 0.31$ & $12.4 \pm 0.30$ \\
\hline 27 & $11.2 \pm 0.35$ & $12.8 \pm 0.31$ \\
\hline 28 & $10.6 \pm 0.23$ & $12.6 \pm 0.35$ \\
\hline 29 & $11.5 \pm 0.31$ & $13.5 \pm 0.31$ \\
\hline 30 & $10.6 \pm 0.06$ & $14.6 \pm 0.30$ \\
\hline 31 & $10.5 \pm 0.20$ & $12.5 \pm 0.35$ \\
\hline 32 & $11.5 \pm 0.31$ & $16.4 \pm 0.45$ \\
\hline 33 & $12.8 \pm 0.36$ & $15.3 \pm 0.50$ \\
\hline 34 & $11.8 \pm 0.25$ & $13.6 \pm 0.36$ \\
\hline 35 & $12.8 \pm 0.35$ & $14.5 \pm 0.31$ \\
\hline 36 & $10.9 \pm 0.31$ & $12.5 \pm 0.36$ \\
\hline 37 & $10.5 \pm 0.25$ & $13.5 \pm 0.31$ \\
\hline 38 & $10.5 \pm 0.31$ & $12.1 \pm 0.25$ \\
\hline 39 & $12.2 \pm 0.31$ & $14.6 \pm 0.25$ \\
\hline 40 & $11.5 \pm 0.26$ & $14.6 \pm 0.25$ \\
\hline 41 & $11.7 \pm 0.31$ & $14.5 \pm 0.30$ \\
\hline 42 & $11.8 \pm 0.25$ & $15.5 \pm 0.31$ \\
\hline Range & $9.3-14.0$ & $12.1-16.4$ \\
\hline Mean & 11.5 & 13.9 \\
\hline SD & 0.92 & 1.02 \\
\hline
\end{tabular}

with low $\mathrm{pH}$ values and high content of oxides of $\mathrm{Fe}$ and Al. Results (table. 6) showed that the red soils were found to be high in adsorbed S (average $2.4 \mathrm{mg} \mathrm{kg}^{-1}$ ) compared to black soils (average $1.5 \mathrm{mg} \mathrm{kg}^{-1}$ ). The possible reason for such occurrence could be due to the low $\mathrm{pH}$ values of red soils. Sulphate adsorption has been attributed to a $\mathrm{pH}$ dependent positive charge typical of acidic soils (Scherer, 2009). In neutral to alkaline soils, there was no appreciable adsorption of sulphur noticed (Shahsavani et al., 2006; Cui et al., 2006).

The regression analysis between the values of $\mathrm{S}$ extracted by $\mathrm{Ca}$ chloride $\left(\mathrm{CaCl}_{2}-\mathrm{S}\right)$ and $\mathrm{Ca}$ phosphate (Ca phos-
Table 4. Extractable $\mathrm{S}\left(\mathrm{mg} \mathrm{kg}^{-1}\right)$ extracted with $0.15 \%$ $\mathrm{CaCl}_{2}(\mathrm{Ca}$ chloride $\mathrm{S})$ and $0.01 \mathrm{M} \mathrm{Ca}\left(\mathrm{H}_{2} \mathrm{PO}_{4}\right)(\mathrm{Ca}$ phosphate $\mathrm{S})$ solutions in 44 soil samples of black soil regions.

\begin{tabular}{|c|c|c|}
\hline Serial No. & $\begin{array}{c}0.15 \% \mathrm{CaCl}_{2} \text { ex- } \\
\text { tractable } \mathrm{S}\end{array}$ & $\begin{array}{c}0.01 \mathrm{M} \mathrm{Ca}\left(\mathrm{H}_{2} \mathrm{PO}_{4}\right) \\
\text { extractable } \mathrm{S}\end{array}$ \\
\hline$T$ & $15.2 \pm 0.40$ & $16.4 \pm 0.95$ \\
\hline 2 & $11.9 \pm 0.40$ & $13.8 \pm 0.46$ \\
\hline 3 & $15.2 \pm 0.35$ & $16.5 \pm 0.40$ \\
\hline 4 & $16.2 \pm 0.35$ & $17.6 \pm 0.86$ \\
\hline 5 & $11.9 \pm 0.50$ & $13.6 \pm 1.12$ \\
\hline 6 & $14.2 \pm 0.30$ & $16.2 \pm 0.70$ \\
\hline 7 & $13.8 \pm 0.35$ & $15.6 \pm 1.15$ \\
\hline 8 & $13.6 \pm 0.36$ & $14.5 \pm 0.70$ \\
\hline 9 & $14.5 \pm 0.31$ & $15.8 \pm 0.75$ \\
\hline 10 & $16.4 \pm 0.23$ & $17.8 \pm 0.96$ \\
\hline 11 & $14.5 \pm 0.26$ & $15.7 \pm 0.64$ \\
\hline 12 & $15.6 \pm 0.32$ & $16.6 \pm 0.76$ \\
\hline 13 & $16.5 \pm 0.25$ & $17.7 \pm 0.58$ \\
\hline 14 & $16.3 \pm 0.40$ & $17.5 \pm 1.05$ \\
\hline 15 & $15.9 \pm 0.35$ & $16.9 \pm 0.38$ \\
\hline 16 & $14.5 \pm 0.25$ & $15.9 \pm 0.81$ \\
\hline 17 & $13.6 \pm 0.35$ & $14.9 \pm 0.46$ \\
\hline 18 & $12.7 \pm 0.26$ & $14.1 \pm 0.66$ \\
\hline 19 & $12.8 \pm 0.46$ & $14.5 \pm 0.85$ \\
\hline 20 & $16.4 \pm 0.26$ & $17.9 \pm 0.46$ \\
\hline 21 & $13.9 \pm 0.57$ & $15.9 \pm 0.74$ \\
\hline 22 & $16.4 \pm 0.56$ & $17.6 \pm 1.01$ \\
\hline 23 & $15.5 \pm 0.32$ & $16.9 \pm 0.82$ \\
\hline 24 & $14.6 \pm 0.32$ & $15.9 \pm 0.50$ \\
\hline 25 & $16.5 \pm 0.31$ & $17.5 \pm 0.31$ \\
\hline 26 & $18.3 \pm 0.21$ & $19.7 \pm 0.58$ \\
\hline 27 & $19.2 \pm 0.40$ & $20.4 \pm 0.61$ \\
\hline 28 & $15.5 \pm 0.31$ & $17.1 \pm 0.31$ \\
\hline 29 & $16.7 \pm 0.46$ & $17.9 \pm 0.55$ \\
\hline 30 & $14.6 \pm 0.17$ & $16.2 \pm 0.45$ \\
\hline 31 & $17.3 \pm 0.46$ & $19.0 \pm 1.10$ \\
\hline 32 & $18.4 \pm 0.46$ & $19.8 \pm 0.85$ \\
\hline 33 & $16.8 \pm 0.66$ & $18.4 \pm 0.49$ \\
\hline 34 & $18.7 \pm 0.44$ & $20.0 \pm 0.53$ \\
\hline 35 & $14.2 \pm 1.19$ & $16.2 \pm 0.60$ \\
\hline 36 & $14.3 \pm 0.51$ & $15.2 \pm 0.65$ \\
\hline 37 & $13.4 \pm 0.74$ & $14.9 \pm 0.81$ \\
\hline 38 & $17.6 \pm 0.51$ & $19.4 \pm 0.53$ \\
\hline 39 & $17.6 \pm 0.25$ & $19.4 \pm 0.87$ \\
\hline 40 & $15.2 \pm 0.89$ & $17.0 \pm 0.50$ \\
\hline 41 & $16.6 \pm 0.35$ & $17.9 \pm 0.56$ \\
\hline 42 & $13.9 \pm 0.53$ & $15.8 \pm 0.60$ \\
\hline 43 & $14.4 \pm 0.46$ & $15.7 \pm 0.58$ \\
\hline 44 & $15.8 \pm 0.60$ & $17.3 \pm 0.46$ \\
\hline Range & $11.9-19.2$ & 13.6- 20.4 \\
\hline Mean & 15.4 & 16.8 \\
\hline $\mathrm{SD}$ & 1.74 & 1.69 \\
\hline
\end{tabular}

phate-S) reagents for all the 86 soil samples studied showed that they were highly significantly correlated $\left(\mathrm{R}^{2}=0.82, \mathrm{n}=86\right)$ (table. 7$)$. Although highly significant correlation coefficient between $\mathrm{Ca}$ chloride and $\mathrm{Ca}$ phosphate extractable $\mathrm{S}$ was found in black soils $\left(\mathrm{R}^{2}=0.97\right)$, Ca phosphate extracted higher amount of $\mathrm{S}$ than Ca chloride solution. Sahrawat et al. (2009) also reported that $\mathrm{Ca}$ phosphate could extract higher amount of S compared to Ca chloride in low $\mathrm{pH}$ soils.

Sulphur availability index: The available sulphur 
Table 5. Correlation coefficients of extractable S (Ca chloride \& Ca phosphate S) and SAI with soil properties and Adsorbed $\mathrm{S}$ in soils of both red and black soil regions.

\begin{tabular}{|c|c|c|c|c|c|c|c|c|c|c|}
\hline \multirow[b]{2}{*}{$\begin{array}{l}\text { Soil } \\
\text { type }\end{array}$} & \multicolumn{3}{|c|}{$\begin{array}{l}\text { Correlation coefficient of } \\
15 \% \mathrm{CaCl}_{2} \text { extractable } \mathrm{S} \text { with }\end{array}$} & \multicolumn{3}{|c|}{$\begin{array}{c}\text { Correlation coefficient of } 0.01 \mathrm{M} \\
\mathrm{Ca}\left(\mathrm{H}_{2} \mathrm{PO}_{4}\right) \text { extractable } \mathrm{S} \text { with }\end{array}$} & \multicolumn{4}{|c|}{ Correlation coefficient of SAI with } \\
\hline & pH & $\underset{\mathrm{C}}{\text { Organic }}$ & $\begin{array}{l}\text { Adsorbed } \\
\text { S }\end{array}$ & pH & $\underset{\mathrm{C}}{\text { Organic }}$ & $\begin{array}{l}\text { Adsorbed } \\
\quad \mathrm{S}\end{array}$ & $\mathbf{p H}$ & $\begin{array}{c}\text { Or- } \\
\text { ganic } \\
\text { C }\end{array}$ & $\begin{array}{l}\text { Ad- } \\
\text { sorbed } \\
\quad \text { S }\end{array}$ & $\begin{array}{c}\mathbf{0 . 0 1 M ~ C a} \\
\left(\mathrm{H}_{2} \mathrm{PO}_{4}\right) \\
\text { extractable } \mathrm{S}\end{array}$ \\
\hline $\begin{array}{l}\text { Red } \\
\text { soils }\end{array}$ & $\begin{array}{l}0.415 \\
* *\end{array}$ & $0.386 * *$ & $-0.589 * *$ & -0.254 & -0.207 & $-0.453 * *$ & $\begin{array}{c}0.433 \\
* *\end{array}$ & $\begin{array}{l}0.581^{*} \\
*\end{array}$ & $\overline{-}^{-} \cdot{ }^{2} 3^{*} *$ & 0.117 \\
\hline $\begin{array}{l}\text { Black } \\
\text { soils }\end{array}$ & 0.012 & 0.293 & -0.254 & 0.05 & 0.296 & -0.087 & 0.011 & $\begin{array}{c}0.409 * \\
*\end{array}$ & -0.234 & $0.980 * *$ \\
\hline
\end{tabular}

** Correlation is significant at the 0.01 level (2-tailed); * Correlation is significant at the 0.05 level (2-tailed)

Table 6. Range and mean values of SAI and Adsorbed S in soils of red and black soil regions.

\begin{tabular}{|c|c|c|c|c|}
\hline \multirow[t]{2}{*}{ Soil type } & \multicolumn{2}{|c|}{ SAI } & \multicolumn{2}{|c|}{ Adsorbed S (mg kg } \\
\hline & Range & Mean & Range & Mean \\
\hline Red soils & $4.0-6.0$ & 5.1 & $0.8-5.9$ & 2.4 \\
\hline $\begin{array}{l}\text { Black } \\
\text { soils }\end{array}$ & $5.0-8.2$ & 6.6 & $0.9-2.1$ & 1.5 \\
\hline
\end{tabular}

fraction, which consists largely of easily extractable sulphate in soils, is the immediate supplier of $\mathrm{S}$ to plant roots. Calcium chloride and mono calcium phosphate solutions are commonly used extractants for predicting the available $\mathrm{S}$ content in soils. But in the present study we considered the Ca chloride extractable $\mathrm{S}$ as available $\mathrm{S}$. However, only the $\mathrm{Ca}$ chloride extractable $\mathrm{S}$ may not be adequate to assess the sulphur availability, as the availability is governed by a number of soil properties (Patra et al., 2012). The shortcoming can be overcome to certain extent by using the Sulphur Availability Index as a key to assess the available $S$ status in soils (Basumatary and Das, 2012). Based on the values of SAI, the red soils were found to be deficient while the black soils were of deficient to medium status. The SAI values of red soils ranged from 4.0-6.0 with an average of 5.1 and in black soil it varied from 5.0-8.2 with an average of 6.6 (table. 6). As the SAI index is a function of $\mathrm{Ca}$ chloride extractable $\mathrm{S}$ and organic matter content of soils, black soils being high in both $\mathrm{Ca}$ chloride extractable $\mathrm{S}$ and organic matter content showed higher SAI values compared to red soils. Patra et al. (2012) found that majority of the soil samples tested of red and lateritic zone of West Bengal were having SAI values below 6.0 and categorized as low status.

Relationship of extractable $\mathbf{S}$ status with soil properties: Correlation coefficients of some important soil characteristics with $\mathrm{Ca}$ chloride and $\mathrm{Ca}$ phosphate extractable S and SAI were presented in table.5. Calcium chloride extractable $\mathrm{S}$ maintained significant positive correlation with SOC $\left(0.386^{* *}\right), \mathrm{pH}\left(0.415^{* *}\right)$ and significant but negative correlation with adsorbed $\mathrm{S}$ ($0.589^{* *}$ ) in red soil regions while no such relationship were observed in black soils regions. Soil organic carbon content of both red and black soils showed significant and positive agreement with SAI while the adsorbed $\mathrm{S}$ maintained significant negative correlation with SAI of red soil regions. Soil $\mathrm{pH}$ maintained sig-
Table 7. Relationships between $\mathrm{S}$ extracted by $0.15 \%$ $\mathrm{CaCl}_{2}(\mathrm{Ca}$ chloride $\mathrm{S})$ and $0.01 \mathrm{M} \mathrm{Ca}\left(\mathrm{H}_{2} \mathrm{PO}_{4}\right)(\mathrm{Ca}$ phosphate $\mathrm{S})$ solutions in red and black soils.

\begin{tabular}{|c|c|c|c|}
\hline $\begin{array}{l}\text { Soil } \\
\text { type }\end{array}$ & $\begin{array}{c}\text { Number of } \\
\text { samples }\end{array}$ & $\begin{array}{c}\text { Regression } \\
\text { equation }\end{array}$ & $\begin{array}{c}\text { Correlation } \\
\text { coefficient } \\
\left(\mathbf{R}^{2}\right)\end{array}$ \\
\hline Red & 42 & $\begin{array}{c}\text { Ca phosphate } \mathrm{S}= \\
11.45+0.21 \mathrm{Ca} \\
\text { chloride } \mathrm{S}\end{array}$ & 0.037 \\
\hline Black & 44 & $\begin{array}{c}\text { Ca phosphate } \mathrm{S}= \\
2.09+0.95 \mathrm{Ca} \\
\text { chloride } \mathrm{S}\end{array}$ & 0.97 \\
\hline $\begin{array}{l}\text { Red- } \\
\text { Black }\end{array}$ & 86 & $\begin{array}{c}\text { Ca phosphate } \mathrm{S}= \\
5.00+0.77 \mathrm{Ca} \\
\text { chloride } \mathrm{S}\end{array}$ & 0.82 \\
\hline
\end{tabular}

nificant positive correlation with SAI in red soils.

\section{Conclusion}

The results of the study emphasized the importance of soil properties on the extractability different reagents for $\mathrm{S}$ in soils. Both the reagents extracted more or less similar amounts of $\mathrm{S}$ in black soils where as in case of red soils $\mathrm{Ca}$ phosphate extracted somewhat high amount of $\mathrm{S}$ compared to Ca chloride solution. However, the amount of available $\mathrm{S}$ was found in the critical region suggesting the need of external supplementation through fertilizers or manures. Application of organics along with chemical fertilizers will be beneficial since it will support the inorganic fraction of $\mathrm{S}$ in case of severe depletion during crop growth and also improve the sulphur availability index (SAI) in soils.

\section{REFERENCES}

Basumatary, A. and Das, K.N. (2012). Forms of sulphur and their relationship with soil properties in some soils of North Bank Plain zone of Assam. A gropedology, 22(1): 43-49

Biswas, H., Rattan, R.K., Datta, S.P. and Singh, A.K. (2003). Adsorption and translocation of sulphur in some tropical acid soils. J. Plant Nutri. Soil Sci., 166: 519-524

Chesnin, L. and Yien, C.H. (1950). Tubidimetric determination of available sulphate. Proc. Soil Sci. Soc. Am., 15:149-151

Cui, X.Y., Wang, S.P., Wang, Y.F., Xing, X.R., Chen, Z.Z., Haneklaus, S., Fleckenstein, J. and Schnug, E. (2006). Suitability of extractants for predicting available sulfur in natural grasslands in the inner Mongolia Steppe of 
China. Commun. Soil Sci. Plant Anal., 37:721-732

Donahue, R.L., Miller, R.W. and Shickluma, J.C. (1977). An introduction to soil and plant growth. $4^{\text {th }}$ edition, prentice hall inc. New jersy, USA, pp 209.

Fox, R.L., Olsen, R.A. and Rhoades, H.F. (1964). Evaluating the sulphur status of soils by plant and soil tests. Soil Sci. Soc. Amer. Proc., 28: 243-246

Ghosh, G.K. and Dash, N.R. (2012). Sulphate sorptiondesorption characteristics of lateritic soils of West Bengal, India. International Journal of Plant, Animal and Environmental Sciences, 2(1):167-176

Haneklaus, S., Bloem, E. and Schnug, E. (2002). Sulphur. In encyclopedia of soil science-soil fertility and plant nutrients. New York, USA: Marcel Dekker.

Jackson, M.L. (1973). Soil chemical analysis. Prentice Hall of India Pvt Ltd, New Delhi.

Kaushal, G.S., Tembhare, B.R. and Sinha, S.B. (1986). Morphology and taxonomy of black soil under Bragi irrigation project in Madhya Pradesh. J. Indian. Soc. soil.sci., 34 (2): 329- 333

Padhan, D. (2014). Sulphur fractions in soils of long-term experiments with various management practices and cropping systems under different agro-ecological zones of India. M.Sc Thesis pp, 1-70.

Padhan, D., Rout, P.P. and Sahoo, T. (2015). Surface and Sub-surface distribution of available potassium in rice growing soils under western central table land Agroclimatic zones of Odisha. Journal of Agroecology and Natural Resource Management, 2(5): 365-368

Padhan, D., Chakraborty, M. and Sen, A. (2016). Fertility status of rice growing soils belonging to different land types under the Western central table land agro-climatic zone of Odisha. International Journal of Ecology and Environmental Sciences, 42(1): 39-45

Pareek, N. (2007). Soil mineralizable sulphur: A sulphur availability index. Journal of Indian Society of Soil Science, 55(3): 289-293

Patra, P., Mondal, S. and Ghosh, G.K. (2012). Status of available Sulphur in surface and sub-surface soils of red and lateritic soils of West Bengal. International Journal of Plant, Animal and Environmental Sciencess, 2(2): 276-281

Rathore, S.S., Shekhawat, K., Kandpal, B.K., Premi, O.P., Singh, G.C. and Singh, D. (2015). Sulphur management for increased productivity of Indian mustard: A review. Annals of Plant and Soil Research, 17 (1): 1- 12

Rego, T.J., Rao, N.V., Seeling, B., Pardhasaradhi, G. and
Rao, K.J.V.D.K. (2003). Nutrient balances- a guide to improving sorghum-and groundnut- based dry land cropping systems in semi-arid tropical India. Field Crops Res., 81: 53-68

Sahrawat, K.L., Murthy, K.V.S. and Wani, S.P. (2009). Comparative evaluation of $\mathrm{Ca}$ chloride and $\mathrm{Ca}$ phosphate for extractable sulfur in soils with a wide range in pH. J. Plant Nutr. Soil Sci., 172: 404-407

Satpathy, S., Mishra, A., Saren, S. and Acharya, B.P. (2015). A Study on soil fertility status of some villages in Nimapara block of East and South-Eastern coastal plain agroclimatic zone of Odisha. International Journal of Chemical and Pharmaceutical Review and Research, 1 (1): $18-23$

Scherer, H.W. (2009). Sulfur in soils. J. Plant Nutr. Soil Sci., 172: $326-335$

Sehgal, J.L. (2012). Soil classification. Fundamental of Soil Science. Indian Society of Soil Science Cambridge printing Works, New Delhi, India, pp 50.

Shahsavani, S., Ardalan, M. and Sistani, K.R. (2006): Sulphate adsorption in soils of North and Northeast Iran. Commun. Soil Sci. Plant Anal., 37:1587-1596

Tandon, H.L.S. (2011). Sulphur in soils, crops and fertilizers. fertilizer development and consultation organization (FDCO), New Delhi.

Thakre, Y.G., Choudhury, M.D. and Raut, R.D. (2012). Physicochemical characterization of red and black soils of Wardha Region. 3 International Journal of Chemical and Physical Science, 1(2): 60-66

Walkley, A. and Black, C.A. (1934). Estimation of organic carbon by the chromic acid titration method. Soil Science, 47:29-38

Wang, J., Solomon, D., Lehmann, J., Zhang, X. and Amelung, W. (2006). Soil organic sulphur forms and dynamics in the Great Plains of North America as influenced by long-term cultivation and climate. Geoderma, 133: $160-172$

Williams, C.H. and Steinbergs, A. (1959). Soil sulphur fractions as chemical indices of available sulphur in some Australian soils. Aust. J. Agril. Res., 10: 340-352

Zhao, F. and Mc Grath, S.P. (1994). Extractable sulphate and organic sulphur in soils and their availability to plants. Plant Soil, 164: 243-250

Zhao, F.J., Mc Grath, S.P., Blake-Kalff, M.M.A., Link, A. and Tucker, M. (2002a). Crop responses to Sslphur fertilization in Europe. Proceedings No.504. International Fertilizer Society, York 